Мельник Л. В. ${ }^{[1 ;}$ ORCID ID: 0000-0003-3628-9160] д.е.н., професор

${ }^{1}$ Національний університет водного господарства та природокористування, м. Рівне

\title{
ОЦІНКА ПЕРЕДУМОВ ФОРМУВАННЯ ДЕПОЗИТНИХ ВКЛАДЕНЬ НАСЕЛЕННЯ У БАНКІВСЬКИХ УСТАНОВАХ
}

У статті розглянуто питання формування депозитної політики банківських установ. Проведено оцінку депозитних ресурсів банківської системи України. Проаналізовано доходи та витрати населення України за 2017-2019 р. Визначено структуру сукупних витрат населення у розрахунку на одне домогосподарство. Досліджено динаміку заощаджень населення. Проведено аналіз депозитів населення у розрізі валют та строків погашення. Надано пропозиції щодо удосконалення механізму залучення депозитних ресурсів у банківських установах.

Ключові слова: заощадження населення; депозити населення; доходи населення; витрати населення; ощадна поведінка.

Ефективне виконання банківською системою покладених на неї функцій, передусім, потребує створення відповідного ресурсного фундаменту. Не маючи достатньої ресурсної бази, банки не можуть реалізовувати інвестиційні проєкти, надавати кредити на поточні потреби юридичним та фізичним особам. Вирішення даного завдання здійснюється у процесі формування ресурсного потенціалу банку, стратегічним джерелом якого виступають заощадження населення.

Формування заощаджень стало невід'ємною частиною фінансової культури більшості народів світу. Населення розвинених країн давно усвідомило необхідність та важливість здійснення заощаджень з метою убезпечення себе від економічних негараздів в майбутньому. Зазвичай населення користується простими та прозорими формами заощаджень, інвестуючи в нерухомість або вкладаючи кошти на строкові депозити. В цьому контексті визначення та оцінка передумов формування депозитних вкладів населення має теоретичне і практичне значення.

Питання формування депозитної бази комерційних банків досліджувалися у наукових працях таких провідних вітчизняних вчених, як О. Васюренко, А.Герасимович, О. Дзюблюк, О. Заруба, В. Лютий, А. Мороз., В. Міщенко, Д. Олійник, М. Савлук, І. Сало та ін. Однак зазначені науковці, розглядаючи проблеми формування 
депозитної бази українських банків, недостатньо уваги приділяють визначенню загальноекономічних факторів та чинників, які дозволять населенню накопичувати заощадження та розміщувати їх у комерційних банках.

Метою даної статті $€$ оцінка сучасних тенденцій ощадної поведінки населення та розроблення теоретико-практичних рекомендацій щодо вдосконалення роботи банку в сфері залучення депозитних коштів.

Депозитну політику банку В.Є. Волохата розглядає в трьох аспектах: як стратегію і тактику банку в частині організації депозитного процесу; як комплекс заходів, що має на меті забезпечення ліквідності банку; як документ, що являє детальний план дій щодо залучення банківських ресурсів [1, С. 310]. У структурі банківських депозитів вагоме місце займають депозити домашніх господарств (табл. 1).

Таблиця 1

Оцінка депозитних ресурсів банківської системи України за 2017-2019 pp.

\begin{tabular}{|l|c|c|c|c|}
\hline \multicolumn{1}{|c|}{ Показники } & \multicolumn{3}{|c|}{ Роки } & 2019 до \\
\cline { 2 - 5 } & 2017 & 2018 & 2019 & $2017, \%$ \\
\hline $\begin{array}{l}\text { Обсяг депозитів, залучених } \\
\text { банками України (млн грн), ут. ч. за } \\
\text { рахунок коштів: }\end{array}$ & 898844 & 932967 & 1071666 & 119,2 \\
\hline - фінансових корпорацій & 28539 & 28234 & 31352 & 109,9 \\
\hline - органів державного управління & 22914 & 23022 & 20924 & 91,3 \\
\hline - нефінансових корпорацій & 343758 & 342503 & 433731 & 126,2 \\
\hline - домашніх господарств & 503633 & 539208 & 585660 & 116,3 \\
\hline
\end{tabular}

Джерело: розраховано автором за даними [2]

Наведені дані свідчать, що протягом аналізованого періоду в банківській системі України спостерігається позитивна тенденція до зрстання обсягів депозитних ресурсів. Так, за період 2017-2019 рр. обсяг залучених банками коштів збільшився на 19,2\%, що свідчить про зростання довіри до банківської системи та розширення асортименту банківських послуг. Найбільше депозитів було залучено банками за рахунок коштів домашніх господарств, питома вага яких становила понад 50\% від загального обсягу залучених депозитів. На другому місці в структурі залучених банками ресурсів - депозити нефінансових корпорацій: 38,2\%; 36,7\%; 40,5\% відповідно. Найменше коштів розміщують на депозити органи державного управління, і ця частка з кожним роком стає все меншою.

Досвід розвинених країн показує, що депозити фізичних осіб $є$ 
найбільш стабільним ресурсом для банку. У той же час роздрібний ринок депозитів $€$ також найбільш вразливим сегментом ринку, на який впливають зростання рівня безробіття та споживчих цін, а також зростання недовіри до банківської системи [3, С. 60].

А тому для успішної реалізації депозитної політики банку необхідно враховувати ряд зовнішніх факторів, які визначаються макроекономічною ситуацією в країні, та внутрішніх, що залежать від діяльності кожного конкретного банку.

Відомо, що головним джерелом формування заощаджень населення $€$ їхні доходи, тому розглянемо обсяг та динаміку доходів населення України за останні 3 роки (табл. 2).

Таблиця 2

Доходи населення України за 2017-2019рр. (млн грн)

\begin{tabular}{|l|c|c|c|c|}
\hline \multicolumn{1}{|c|}{ Показники } & \multicolumn{3}{|c|}{ Роки } & $\begin{array}{l}2019 \text { до } \\
2017, \%\end{array}$ \\
\cline { 2 - 5 } & 2017 & 2018 & 2019 & 139,5 \\
\hline Доходи, всього: & 2652082 & 3248730 & 3699346 & 145,0 \\
\hline - заробітна плата & 1209097 & 1529367 & 1753337 & 145,0 \\
\hline - прибуток та змішаний дохід & 477854 & 572065 & 678275 & 141,9 \\
\hline $\begin{array}{l}\text { - доходи від власності } \\
\text { (одержані) }\end{array}$ & 78673 & 91164 & 94481 & 120,1 \\
\hline $\begin{array}{l}\text { - соціальні допомоги та інші } \\
\text { одержані поточні трансферти }\end{array}$ & 886458 & 1056134 & 1173253 & 132,4 \\
\hline Наявний дохід & 2008278 & 2470325 & 2838056 & 141,3 \\
\hline $\begin{array}{l}\text { Наявний дохід у розрахунку } \\
\text { на одну особу, грн }\end{array}$ & 47270 & 58442 & 67528 & 142,9 \\
\hline $\begin{array}{l}\text { Реальний наявний дохід, у \% } \\
\text { до попереднього року }\end{array}$ & 110,9 & 110,9 & 106,5 & - \\
\hline
\end{tabular}

Джерело: розраховано автором за даними [4; 5]

Згідно з даними табл. 2 очевидно, що протягом 2017-2019 рр. загальна сума доходів населення має тенденцію до зростання, що, безумовно, $\epsilon$ позитивним явищем. Так, у 2018 р. доходи населення зросли на 596648 млн грн (або на 22,5\%) порівняно з 2017 р., а у 2019 р. - на 450616 млн грн (13,9\%) порівняно з 2018 р. В цілому за аналізований період відбулося зростання доходів на $39,5 \%$.

У структурі доходів населення переважає заробітна плата. Протягом досліджуваного періоду частка заробітної плати була досить стабільною і становила 45-47\%. Для порівняння: у країнах ЄС заробітна плата займає близько $70 \%$ в структурі грошових доходів населення.

Значну частину в структурі доходів займають соціальні допомоги та інші трансферти: 33,4\%; 32,5\%; 31,7\% відповідно. Таким чином, можна зробити висновки, що в Україні відтворювальна 
функція заробітної плати реалізується недостатньо. Низька оплата праці відчутно гальмує зростання платоспроможності населення України і процеси формування заощаджень.

Як відомо, частину наявного доходу людина використовує спочатку на витрати, а іншу (залишок доходу після вирахування всіх витрат) - на заощадження. Найчастіше під терміном «заощадження» розуміють систему економічних відносин між суб'єктами з приводу формування, збереження та використання грошових коштів та фінансових ресурсів. Макконелл К.Р., БрюС.Л. визначають заощадження як різницю між доходами та витратами на споживання, що, по суті, означає невикористання частини доходу на споживання [6]. Проаналізуємо динаміку витрат населення України за останні 3 роки (табл. 3).

Таблиця 3

Динаміка витрат населення України за 2017-2019рр. (млн грн)

\begin{tabular}{|l|c|c|c|c|}
\hline \multicolumn{1}{|c|}{ Показники } & \multicolumn{3}{|c|}{ Роки } & 2019 до \\
\cline { 2 - 4 } & 2017 & 2018 & 2019 & $2017, \%$ \\
\hline $\begin{array}{l}\text { Витрати всього, } \\
\text { ут. ч. на: }\end{array}$ & 2652082 & 3248730 & 3699346 & 139,5 \\
\hline - придбання товарів та послуг & 2359985 & 2884971 & 3406202 & 144,3 \\
\hline $\begin{array}{l}\text { - доходи від власності } \\
\text { (сплачені) }\end{array}$ & 21561 & 29975 & 39273 & 182,1 \\
\hline $\begin{array}{l}\text { - поточні податки на доходи, } \\
\text { майно та інші сплачені } \\
\text { поточні трансферти }\end{array}$ & 239898 & 302237 & 370036 & 154,2 \\
\hline
\end{tabular}

Джерело: розраховано автором за даними [4; 5]

Дані табл. 3 показують, що разом 3 отриманими доходами населення збільшило і свої витрати. Найбільшу частку в структурі витрат населення займають витрати на придбання товарів та послуг, які зросли за аналізований період на 44,3\% та становлять в середньому 90\%. Досить вагоме місце у структурі витрат займають податки та інші сплачені трансферти - близко10\%. Для того, щоб оцінити можливості населення України заощаджувати кошти, вважаємо за необхідне дослідити сукупні витрати, які, в середньому, витрачає одне домогосподарство за місяць (табл. 4).

Згідно 3 даними табл. 4, розмір суми сукупних витрат в середньому на одне домогосподарство щороку збільшується. Так, у 2019 р., порівняно 32017 р., сукупні витрати збільшились на 2530,8 млн грн (або на 35,4\%). Очевидно, що найбільше населення України за основними статтями витрачає на продукти харчування та безалкогольні напої (понад 50\%), а також на житло, воду, 
електроенергію, газ та інші види палива (близько 13\%).

Таблиця 4

Структура сукупних витрат населення України за 2017-2019 рр.

(у середньому за місяць у розрахунку на одне домогосподарство)

\begin{tabular}{|l|c|c|c|c|c|}
\hline \multirow{2}{*}{ Показники } & & & & \multicolumn{2}{|c|}{$\begin{array}{c}\text { Абсолютне } \\
\text { відхилення }\end{array}$} \\
\cline { 5 - 7 } & 2017 р. & 2018 р. & 2019 р. & $\frac{2018}{2017}$ & $\frac{2019}{2018}$ \\
\hline Усього сукупних витрат, грн & 7139,4 & 8308,6 & 9670,2 & 1169,2 & 1361,6 \\
\hline Споживчі сукупні витрати, \%: & 92,9 & 92,0 & 91,3 & $-0,9$ & $-0,7$ \\
\hline - продовольчі товари,\% & 52,7 & 52,8 & 51,7 & 0,1 & $-1,1$ \\
\hline $\begin{array}{l}\text { - непродовольчі товари та } \\
\text { послуги, \%, в т.ч. }\end{array}$ & 40,2 & 39,2 & 39,6 & $-1,0$ & 0,4 \\
\hline оплата житла та послуг, \% & 15,4 & 13,9 & 13,0 & $-1,5$ & $-0,9$ \\
\hline Неспоживчі сукупні витрати, \% & 7,1 & 8,0 & 8,7 & 0,9 & 0,7 \\
\hline
\end{tabular}

Джерело: розраховано автором за даними [4; 5]

Найменше населення витрачає свої кошти на освіту $(1,1 \%)$ та відпочинок і культуру (1,6\%). У країнах Заходу сім"ї із середнім добробутом витрачають на їжу від 16\% до 25\% бюджету (у США 10\%). За цим критерієм у США вважаються бідними родини, якщо вони витрачають на їжу понад 33\% сімейного бюджету [7].

Представлена структура витрат свідчить про зменшення добробуту домогосподарств, що впливає на формування та використання їх фінансових ресурсів. Це підтверджується даними про динаміку та обсяг заощаджень населення України, що представлено в табл. 5.

Таблиця 5

Динаміка заощаджень населення України за 2017-2019 рр., (млн грн)

\begin{tabular}{|l|c|c|c|}
\hline \multirow{2}{*}{\multicolumn{1}{|c|}{ Показники }} & \multicolumn{3}{|c|}{ Роки } \\
\cline { 2 - 4 } & 2017 & 2018 & 2019 \\
\hline Заощадження всього: & 30638 & 31547 & -116165 \\
\hline - нагромадження нефінансових активів & -32060 & -22889 & -21148 \\
\hline - приріст фінансових активів & 62698 & 54436 & -95017 \\
\hline
\end{tabular}

Джерело: розраховано автором за даними [4; 5]

Дані табл. 5 показують неоднозначні тенденції в обсягах заощаджень населення України, що свідчать про непевність населення у виборі між неорганізованими (більш надійними, 3 погляду громадян) та організованими (більш прибутковими) формами заощаджень. Так, у 2018 р. відповідно до 2017 р. вони зросли на 909 млн грн (або на 2,97\%). А в 2019 році відбувається 
різке зменшення заощаджень - на 150 млрд грн, і показник заощаджень приймає від'ємне значення, що свідчить про те, що населення не заощаджує, а використовує раніше заощадженні кошти.

Окрім того, розглядаючи структуру заощаджень зазначимо, що громадяни України у 2017-2018 роки віддавали перевагу заощадженням у вигляді фінансових активів, а у 2019 р. приріст фінансових активів має негативну динаміку. Отже, населення України за 2017 р. загалом змогло заощадити лише 1,2\% власного доходу, у 2018 р. - 1\% (що на 0,2 пункти менше, ніж за 2017 р.). у 2019 р. українці втратили 3,2\% доходу, які б мали спрямувати у заощадження, що у грошовому еквіваленті дорівнює 116165 млн грн.

Попри це, аналіз депозитних вкладень населення свідчить, що депозити фізичних осіб, розміщені в установах комерційних банків, мають динаміку до зростання (табл. 6).

Таблиця 6

Депозити домашніх господарств України у розрізі валют за 2017-2019 рр. (млн грн)

\begin{tabular}{|l|c|c|c|c|}
\hline \multicolumn{1}{|c|}{ Показники } & \multicolumn{3}{|c|}{ Роки } & $\begin{array}{l}2019 \text { до } \\
2017, \%\end{array}$ \\
\cline { 2 - 4 } & 2017 & 2018 & 2019 & 116,3 \\
\hline $\begin{array}{l}\text { Депозити всього, } \\
\text { т. ч. депозити в: }\end{array}$ & 495313 & 530250 & 576126 & 134,4 \\
\hline - національній валюті (гривня) & 252439 & 279416 & 339168 & 97,6 \\
\hline - іноземній валюті: & 242874 & 240833 & 236958 & 97,4 \\
\hline - долар США & 203681 & 202567 & 198405 & 98,6 \\
\hline - євро & 38060 & 37207 & 37539 & 89,4 \\
\hline - інші валюти & 1134 & 1059 & 1014 & 8 \\
\hline
\end{tabular}

Джерело: розраховано автором за даними [2]

Так, за досліджуваний період обсяг депозитів домашніх домогосподарств зріс на 16,3\%. у 2018 р. сума депозитів збільшилась на 34937 млн грн (або на 7,1\%) порівняно з 2017 р., а у 2019 р. ще зросла на 45876 млн грн (або на 8,7\%) відповідно до 2018 р. Населення України віддає перевагу депозитам в національній валюті, питома вага яких зросла на $8,9 \%$ і становила у 2019 році в загальному їх обсязі 58,9\%. Депозити ж в іноземній валюті показують спадну тенденцію: у 2019 р. депозити в іноземній валюті зменшились на 2,4\% порівняно з 2017 роком. Це зменшення, насамперед, обумовлено зменшенням обсягу депозитів в доларах США, яким населення віддає перевагу: майже $84 \%$ від загального обсягу депозитів в іноземній валюті припадало в 2019 році на 
долари США.

Свідоцтвом довіри до комерційних банків $є$ строки, на які вкладає свої кошти населення в дані установи (табл. 7).

Таблиця 7 Депозити домашніх господарств України у розрізі строків погашення за 2017-2019 рр. (млн грн)

\begin{tabular}{|l|c|c|c|c|}
\hline \multirow{2}{*}{ Показники } & \multicolumn{3}{|c|}{ Роки } & 2019 до \\
\cline { 2 - 4 } & 2017 & 2018 & 2019 & $2017, \%$ \\
\hline Депозити всього, у т. 4.: & 495313 & 530250 & 576126 & 116,3 \\
\hline - на вимогу & 165978 & 203410 & 240125 & 144,7 \\
\hline - до 1 року & 181092 & 210188 & 237690 & 131,2 \\
\hline - від 1 до 2 років & 142017 & 109895 & 92669 & 65,3 \\
\hline - більше 2 років & 6227 & 6757 & 5642 & 90,6 \\
\hline
\end{tabular}

Джерело: розраховано автором за даними [2]

Очевидно, що найбільше домашні господарства розміщують кошти у депозити на вимогу та у депозити строком погашення до 1 року. Протягом 2017-2019 рр. обсяг цих депозитів зростав найвищими темпами, натомість всі інші депозитні вкладення скорочувались. У 2019 році обсяг короткострокових та поточних депозитів становив майже 83\% від загальної їх суми, проти $70 \%$ у 2017 році. Найменше населення України зацікавлене у розміщенні тимчасово вільних коштів на довгострокові депозитні рахунки менше 1\%. Окрім того, набирає популярність і вкладення заощаджень населення в ОВДП, динаміку та обсяг яких представлено у табл. 8.

Таблиця 8

ОВДП, які знаходяться в обігу за номінально-амортизаційною вартістю у 2017-2019 рр. (млрд грн)

\begin{tabular}{|l|c|c|c|c|}
\hline \multirow{2}{*}{ Власники облігацій } & \multicolumn{3}{|c|}{ Роки } & 2019 до \\
\cline { 2 - 4 } & 2017 & 2018 & 2019 & $2017, \%$ \\
\hline Усього ОВДП: & 632,29 & 624,14 & 725,26 & 114,7 \\
\hline - НБУ & 360,57 & 348,1 & 337,08 & 93,5 \\
\hline - банки & 248,66 & 253,89 & 247,12 & 99,4 \\
\hline - юридичні особи & 17,7 & 14,38 & 20,8 & 117,5 \\
\hline - фізичні особи & 0,23 & 1,62 & 4,12 & 1791,3 \\
\hline - нерезиденти & 5,13 & 6,15 & 116,14 & 2263,9 \\
\hline
\end{tabular}

Джерело: розраховано автором за даними [8]

Очевидно, що найбільшу частку ОВДП тримає НБУ та комерційні банки $-46,5 \%$ і 34,1\% відповідно. Юридичні та фізичні особи в сумі мають 3,5\% від загальної вартості ОВДП, проте спостерігається тенденція до зростання величини коштів, розміщених в дані 
фінансові активи, що пов'язано з меншою їх ризиковістю. Однак лідером $€$ все-таки депозити, як найбільш зручні та прості у використанні, оскільки ОВДП передбачають дещо складніший механізм придбання та повернення коштів.

Так, поклавши кошти на депозит в банку їх можна зберегти, але при цьому частина доходу втрачається через наявну в країні інфляцію. Інвестори зазвичай отримують більше прибутку при вкладанні коштів в інші, більш ризикові активи. Разом 3 тим, банківські депозити мають мінімальний ризик, адже повернення коштів гарантує держава через Фонд гарантування вкладів фізичних осіб. Те ж саме відбувається і з ОВДП, які також випускаються під гарантію держави.

Гарантії від держави є надзвичайно важливим інструментом впливу на прийняття рішень щодо розміщення своїх коштів на депозити. В цьому контексті вважаємо за необхідне законодавчо забезпечити підвищення граничного рівня відшкодування з боку Фонду гарантування вкладів фізичних осіб, який сьогодні становить 200 тис. грн незалежно від кількості рахунків в одному банку, як мінімум у 2 рази.

Це дозволить вкладникам не «дробити» свої вклади, а тримати більше коштів на одному депозитному рахунку. Тому що, як показує практика, строки вкладання коштів безпосередньо залежать від розміру депозитів: великі суми вкладаються переважно на триваліший термін. А однією із проблем, яка не дозволяє використовувати депозитні кошти як інвестиційний ресурс в економіку країни, $є$ їх занадто короткий термін.

Більшої уваги потребує розвиток депозитних операцій із впровадженням нових програмних продуктів, таких як депозит 3 програмою страхування, відсотки за яким спрямовуються страховій компанії на накопичувальний рахунок або як оплата туристичної страховки тощо.

Необхідно активно застосовувати комплексне обслуговування клієнтів для підвищення конкурентоспроможності банку та проводити систематичну роботу над покращенням його ділової репутації.

Окрім того, варто зауважити, що заощадження населення формуються переважно за рахунок коштів з оплати праці. Відтак, недостатній рівень заробітної плати в країні знижує не тільки рівень споживання населення, але й рівень заощаджень. Натомість висока заробітна плата, навпаки, підвищує ощадну активність населення, а через це й рівень інвестиційного потенціалу країни. 
1. Волохата В. Є. Фактори формування депозитних ресурсів банку. Бізнесінформ. 2013. № 8. С. 310-316. 2. Статистичний бюлетень HБУ. URL: http://www.bank.gov.ua/Statist/electronic\%20bulletin/el_bul_102008.pdf> (дата звернення: 10.11.2020). 3. Волкова В. В., Іноземцева Є. В. Концептуальні засади удосконалення формування ресурсного потенціалу банку. Економіка і організація управління. 2018. № 4. С. 56-64. 4. Державна служба статистики України : вебсайт. URL: http://www.ukrstat.gov.ua (дата звернення: 15.11.2020). 5. Статистичний щорічник України за 2019 рік. Державна служба статистики України. 2019. 409 с. URL: http://www.ukrstat.gov.ua/druk/publicat/kat_u/publ1_u.htm (дата звернення: 12.11.2020). 6. Макконелл К. Р., Брю С. Л. Экономикс: принципы, проблемы и політика : учебник. Москва : Инфра-М, 2017. 1028 с. 7. Рейтинг країн за видатками на їжу. URL: https://www.unian.ua/economics/agro/10858439 (дата звернення: 20.11.2020). 8. Міністерство фінансів України : веб-сайт. URL : https://mof.gov.ua/uk (дата звернення: 15.11.2020).

\section{REFERENCES:}

1. Volokhata V. Ye. Faktory formuvannia depozytnykh resursiv banku. Biznesinform. 2013. № 8. S. 310-316. 2. Statystychnyi biuleten NBU. URL: http://www.bank.gov.ua/Statist/electronic\%20bulletin/el_bul_102008.pdf> (data zvernennia: 10.11.2020). 3. Volkova V. V., Inozemtseva Ye. V. Kontseptualni zasady udoskonalennia formuvannia resursnoho potentsialu banku. Ekonomika i orhanizatsiia upravlinnia. 2018. № 4. S. 56-64. 4. Derzhavna sluzhba statystyky Ukrainy : veb-sait. URL: http://www.ukrstat.gov.ua (data zvernennia: 15.11.2020). 5. Statystychnyi shchorichnyk Ukrainy za 2019 rik. Derzhavna sluzhba statystyky Ukrainy. 2019. 409 s. URL: http://www.ukrstat.gov.ua/druk/publicat /kat_u/publ1_u.htm (data zvernennia: 12.11.2020). 6. Makkonell K. R., Bryu S. L. Ekonomiks: printsipyi, problemyi i politika : uchebnik. Moskva : Infra-M, 2017. 1028 s. 7. Reitynh krain za vydatkamy na yizhu. URL: https://www.unian.ua/economics/agro/10858439 (data zvernennia: 20.11.2020). 8. Ministerstvo finansiv Ukrainy : veb-sait. URL : https://mof.gov.ua/uk (data zvernennia: 15.11.2020).

Melnyk L. V. [1; ORCID ID: 0000-0003-3628-9160], Doctor of Economics, Professor

${ }^{1}$ National University of Water Management and Environmental Engineering, Rivne

\section{ASSESSMENT OF PREREQUISITES FOR FORMATION OF HOUSEHOLD DEPOSITS IN BANKING INSTITUTIONS}

Effective performance of functions by the banking system requires the creation of an appropriate resource foundation. The solution of this problem is carried out in the process of forming the resource potential of the bank, the strategic source of which are the savings of the population.

The purpose of this article is to assess current trends in savings behavior of the population and the development of theoretical and practical recommendations for improving the bank's work in attracting deposits.

The article considers the theoretical aspects of the formation of deposit policy as a strategy and tactics of the bank in the organization of the deposit process; as a set of measures aimed at ensuring the liquidity of the 
bank; as a document that is a detailed action plan for attracting banking resources.

An assessment of deposit resources of the banking system of Ukraine was made and it was established that in the banking system of Ukraine there is a positive tendency to increase the volume of deposit resources, primarily at the expense of households. The internal factors of the bank's deposit policy implementation, which depend on the activity of each specific bank, and the external factors, which are determined by the macroeconomic situation in the country, have been singled out. The structure and dynamics of incomes and expenditures of the population of Ukraine for 2017-2019 have been analyzed. It has been established that the structure of incomes of the population is dominated by wages and social benefits and other transfers; in the cost structure - the cost of purchasing goods and services. The structure of total expenditures of the population per household is determined, which indicates that the population spends the most on food and housing. The dynamics of savings is studied and ambiguous tendencies in their volumes are established, which testify to the uncertainty of the population in the choice between organized and unorganized forms of savings. Analysis of household deposits in terms of currencies and maturities has been conducted. It is noted that the population of Ukraine prefers short-term deposits in the national currency, which have a dynamic growth. Suggestions for improving the mechanism for attracting deposit resources in banking institutions have been provided.

Keywords: savings of the population; household deposits; household income; population expenditures; frugal behavior.

Мельник Л. В. ${ }^{[1 ;}$ ORCID ID: 0000-0003-3628-9160], д.э.н., профессор

${ }^{1}$ Национальный университет водного хозяйства и природопользования, г. Ровно

\section{ОЦЕНКА ПРЕДПОССЫЛОК ФОРМИРОВАНИЯ ДЕПОЗИТНЫХ ВКЛАДОВ НАСЕЛЕНИЯ В БАНКОВСКИХ УЧРЕЖДЕНИЯХ}

В статье рассмотрены вопросы формирования депозитной политики банковских учреждений. Проведена оценка депозитных ресурсов банковской системы Украины. Проанализированы доходы и расходы населения Украины за 2017-2019 г. Определена структура совокупных расходов населения в расчете на одно домохозяйство. Исследована динамика сбережений населения. Проведен анализ депозитов населения в разрезе валют и сроков погашения. Даны предложения по совершенствованию механизма привлечения депозитных ресурсов в банковских учреждениях.

Ключевые слова: сбережения населения; депозиты населения; доходы населения; расходы населения; сберегательное поведение.

Стаття надійшла до редакції 16.11.2020 р. 